\title{
Intra-Muslim Dialogue: The Litmus Test for Islam as a Credible Partner
}

\author{
Christoph Marcinkowski*
}

Closely connected to a discussion of the practical goals and objectives of Islamic law or maqāșid al-sharī 'ah - the subject of this journal's Special Issue - and to

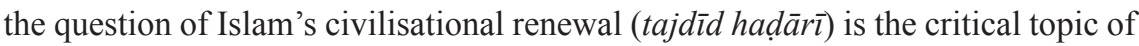
openness for dialogue with those who hold views that are different from our own.

Recent years have witnessed several initiatives by both Muslims and non-Muslims toward getting to know and respect each other better - especially (but by no means only) in the aftermath of Pope Benedict XVI's controversial 'Regensburg lecture' of 12 September 2006. ${ }^{1}$ Dialogue between Muslims and non-Muslims has now become one of the key realities of daily life, resulting in many international conferences and much publicised high-level meetings between representatives of Islamic thought and spirituality and of the other major religions.

However, the practical outcome of such initially auspicious events is all too often relatively meagre. In order to make intercivilisational dialogue more meaningful - and long-lasting - it would also be necessary to look inward. In line with such an approach, each member of such a dialogue project could ask himself about the 'dialogueability' among members of one's own civilisation, faith, and society in this regard. The manner in which we tend to deal with real (or imagined) dissent within our own ranks determines logically the way in which we are facing 'the Other'.

Catholic Christians, for instance, sometimes complain about real or perceived restrictions in countries dominated by another faith or worldview - quite recently, this happened also in this country, Malaysia. At times, they also deplore the supposed 'moral decadence' of Western secular societies. Certain revelations of the last decades - and in particular under the pontificates of the present pope as well as that of his predecessor John Paul II - however, have clearly shown that the Church, too, is not immune to moral transgressions and even criminal behaviour from a certain number of its clerics. We need only to recall the seemingly fathomless morass of sexual perversion and paedophilia among apparently larger than previously thought sectors of the clergy worldwide, along with hypocrisy and attempts to cover-up, the support of rather unsavoury regimes during the Cold War, sinister financial transactions, or the silencing of dissent and voices of reform. This might say nothing about the majority of priests and regulars who have remained blameless and display

* Dr Christoph Marcinkowski is Principal Research Fellow at IAIS Malaysia and Co-Chair of Publications. 
selfless charity, but it nevertheless places on the Church the responsibility of clearing up the mess among its own ranks before 'throwing the first stone'.

On the other hand, however, a think tank like IAIS Malaysia which has a mainly Muslim audience in mind, cannot lay back, taking delight in the moral failures of 'the Other', the 'evil West'. In order to be a credible partner for interfaith dialogue - not to mention the moral and spiritual tenets of Islam in toto - Muslims too need to look inward, into their own societies.

The questions which they could ask themselves are: How have Muslims dealt with dissent in the past and present? Is the political instability of many Muslim countries in the Middle East (and beyond) the result of such insecurity in dealing with opposition within their own ranks? Why do internal conflicts often result in violence and bloodshed? Is the centuries-old conflict between Sunnites and Shi'ites, for instance, to be seen as one of the outcomes of such a problem of dealing with dissent? What about the plight of religious minorities within such a bleak setting (Ahmadis and Baha'is in Pakistan and Iran, respectively, come to mind)?

Moreover, what about the role of the sharī'ah within such a scenario? Is it really invoked in order to help people or rather as a sign of a 'holier-than-thou' attitude. People from another religious tradition know well the story of Jesus, when he was asked one day by his Disciples why he carried out his healing of the sick and other beneficial works on the Sabbath, the Jewish day of rest. He is said to have replied, "The Sabbath was made for humankind, and not humankind for the Sabbath". ${ }^{2}$ Now if we were to 'islamise' this, one could well say that Islamic law is there to help Muslims on their way to become closer to God (which is actually also closest to the etymology of the Arabic word sharì ah, so often invoked by its supposed supporters).

In short, right answers and right solutions to such and other questions would certainly help to clear up the rather sad image that Islam - and sometimes even religion in general - is currently 'enjoying' among many people worldwide. Truly, Muslims - as well as people of other faiths - have a special responsibility.

Among the overall solutions for such a depressing scenario would be the move toward more open and inclusive Muslim societies - based on more positive precedents of the past and lessons learned in the present. From among the Muslimdominated nations, post-Suharto Indonesia has perhaps made the most promising progress - promising also because Indonesia is numerically the strongest Muslim nation on this planet. Malaysia, too, has shown - especially after the 2008 general elections - that it can deal with certain changes in the political spectrum.

However, all too often Islam - a world religion with universal moral and spiritual tenets - is 'hijacked' not only by radicals of various sorts, ${ }^{3}$ but also by political settings and countries that do not usually feature in the headlines of the international media as 'rogue states'. Unfortunately, some of those players consider Islam the 
domain of one particular ethnic group, making it therefore rather difficult for non-Muslim citizens to feel at home or to connect with their Muslim compatriots - although they too are loyal taxpayers and perhaps living even for centuries in the country. Some others like to harp on about the real (or imagined) Sunnite-Shi'ite divide in order to perpetuate their grip on power. Other systems, in turn, tend to focus on one particular Muslim 'legal school' (madhhab) as the only acceptable thing on earth, sometimes even outlawing the remaining three orthodox 'schools' of Sunnite jurisprudence. Although all this often takes place 'in the name of Islam', the damage to the image of that religion and to that of the ummah - the global Muslim community - is often devastating.

History has shown - and continues to show - that societies that are inclusive and based on cultured dialogue are much more resilient and stable in times of social and economic challenges and crises. In turn, societies that are based on prejudice and the prevalence of one particular interpretation of reality, tend to be unstable and prone to aggression toward 'the Other'. Sometimes internal tensions even result in wars with neighbouring countries.

\section{Some Recommendations}

As this writer has argued in a previous Viewpoint, ${ }^{4}$ Malaysia, for instance, is currently at such a crossroads. The 1Malaysia policy of the country's Najib administration, combined with a renewed effort by IAIS Malaysia to present Tun Abdullah Ahmad Badawi's Islam Hadhari concept to the local Muslims (hopefully also in Malay, the language where all this would matter most) are certainly steps in the right direction.

The Najib administration has recognised the danger of the emergence of two 'parallel societies' in Malaysia: one dominated by those interested in a more open and inclusive society and another made up by self-appointed supposedly orthodox 'religious leaders' who consider their brand of Islam the one and only.

- The Najib administration and its 1Malaysia approach, however, need the support of all well-meaning people, in this country and abroad - and in order to get such support Putrajaya needs to tap all resources and reach out also to those who harbour different views.

- Based on the demands of maqāsid al-sharī'ah, and in terms of opening up Malaysian society at large and the Malay-Muslim setting in particular, Malaysia's current administration has recognised the signs of our times.

- What remains to be done is to convey this maqāsid-based inclusive concept of Islam to the less educated, mostly rural constituency.

- Indeed, although this is often seen as an issue too sensitive to tackle, to do so would amount to true leadership for which generations to come - Muslims 
as well as non-Muslims - would be grateful. It would be a new 'struggle for independence', keeping Malaysia together and building a climate of trust and mutual respect. It would certainly add to the credibility of Islam when doing dialogue with 'the Other'.

\section{Notes}

1. See Christoph Marcinkowski, "Religion, Reason, 'Regensburg': Perspectives for Catholic-Muslim Dialogue", Islam and Civilisational Renewal (Special Issue: Islam and Pluralism) 1, no. 1 (October 2009), 159-67.

2. Mk 2:27 (tr. New Revised Standard Version).

3. See Christoph Marcinkowski, “'Kidnapping' Islam? Some Thoughts on Southern Thailand's Muslim Community Between Ethnocentrism and Constructive Conflict-Solution", Islamic Culture 78, no. 2 (2004), 79-86 (also available online at http://mis-pattani.pn.psu.ac.th/registra/grade/temp/ speech/20020823/Panel18\%5B1\%5D.doc, accessed on 17 September 2010).

4. Christoph Marcinkowski, "Whither, Malaysia? A Multicultural Country at the Crossroads", Islam and Civilisational Renewal 1, no. 4 (July 2010), 705-9. 